\section{Håp om en hivvaksine}

Siden oppdagelsen av hiv-1 i 1984 har gjentatte fors $ø$ k på å utvikle en hivvaksine vist seg vanskelig, blant annet fordi viruset muterer hyppig. De fleste vaksiner virker ved å stimulere produksjon av antistoff som nøytraliserer det infeksiøse agenset, men tidlig i 1990-årene hadde man ikke sett nøytraliserende effekt på hiv-1 av vaksineinduserte antistoffer. Derfor ble strategien endret i retning av fors $ø$ k på å stimulere cellemediert immunitet. Dette kan ikke hindre smitte, men kan i teorien bremse progresjon fra smitte til sykdom. Heller ikke denne strategien har gitt noen effektiv vaksine så langt (1).

Håpet om allikevel å kunne utvikle en vaksine som gir nøytraliserende antistoffer fikk nytt liv i januar 2009. En svensk studie viste at en stor andel av menn som har hatt reseptiv oralsex med hivpositive menn uten selv å bli smittet, produserer hivnøytraliserende lgA-antistoff (2).

Nylig økte optimismen ytterligere da en fase 2-studie $i$ Thailand viste tendens til beskyttende effekt av fire injeksjoner med rekombinant kanarifuglkoppevirus (ALVAC-HIV [vCP1521]) samt to forsterkningsdoser med rekombinant glykoprotein 120 (AIDSVAX B/E), som inneholder deler av overflatemolekyler fra hiv-1. 16402 forsøkspersoner ble randomisert til vaksine eller placebo. Samlet observasjonstid var 52985 personår. Behandlingsintensjonsprinsippet og per protokoll-analysene viste tendens til beskyttende effekt mot senere hivinfeksjon, men $p$-verdiene var ikke statistisk signifikante $(0,08$ og 0,16$)$. Man fant imidlertid ut at fem av personene i intervensjonsgruppen og to personer i placebogruppen hadde vært hivinfisert allerede ved inklusjon. Ved eksklusjon av disse sju fra analysen (behandlingsintensjon) fant man en beskyttende effekt på 31,2 \% $(95 \% \mathrm{KI}$ $1,1-51,2, p=0,04)(3)$. Dette gir håp om at det kan være mulig å utvikle en effektiv hivvaksine som er egnet for massevaksinasjon.

\section{Kristoffer Brodwall}

kristoffer.brodwall@gmail.com

Barneavdelinga

Ålesund sjukehus

\section{Litteratur}

1. Miedema F. A brief history of HIV vaccine research: stepping back to the drawing board? AIDS 2008; 22: 1699-703

2. Hasselrot K, Säberg P, Hirbod T et al. Oral HIV-exposure elicits mucosal HIV-neutralizing antibodies in uninfected men who have sex with men. AIDS 2009; 23: 329-33.

3. Rerks-Ngarm S, Pitisuttithum P. Nitayaphan S. Vaccination with ALVAC and AIDSVAX to Prevent HIV-1 Infection in Thailand. N Eng J Med; e-publisert 20.10.2009. http://content. nejm.org/cgi/content/full/NEJMoa 0908492v2 (16.11.2009).

\title{
Koleraepidemien som endelig tok slutt
}

\author{
Hvor kommer denne ideen fra? Hvorfor må jeg absolutt reise til et av \\ de mest vanstyrte landene i verden? Hva kan vel jeg bidra med i kolera- \\ epidemien som herjer landet? Disse tankene farer gjennom hodet da \\ jeg lander på flyplassen i Harare i januar 2009. Ti dager senere har \\ jeg funnet noen svar på hvorfor epidemien har spredd seg så uhindret \\ i et halvt år.
}

Det er nesten ufremkommelig i Nelson Mandela-gaten 30. januar 2009. Folk venter tålmodig i timer for å få et glimt av den nye statsminister Tsvangirai på vei til kontoret. Jeg haster av gårde for å nå en avtalt skyss til Mutare der Metodistkirken har et sykehus. Jeg venter det meste av dagen, men skyssen min dukker ikke opp. Det er ingen kontakt på mobil. I stedet sitter jeg på med en trailer som går tidlig neste dag med materialer til noen sykehus. Vi sitter sju stykker i førerhuset, trangt, men hyggelig.

\section{Koleraepidemien}

Vi kommer ganske fort ut av bykjernen med moderne høyhus (fig 1). Nå er det små, lave hus med en liten hageflekk rundt. Traileren må stoppe til stadighet. Det er filteret som tetter seg, og sjåføren tar til slutt vekk hele filteret, og da kjører vi videre uten problemer. Jeg drar kjensel på navnet Chitungwiza. Det var her koleraepidemien startet i slutten av august 2008. Det såkalte indekskasuset sies å ha vært en handelsmann som fikk kolera i Mosambik og som senere smittet sine to barn. Alle tre døde, forteller mitt reisefølge, som er aidskoordinator.

Epidemien har spredd seg med lynets hastighet over nesten hele Zimbabwe. Tilstoppet kloakk med lekkasje til vannrør har

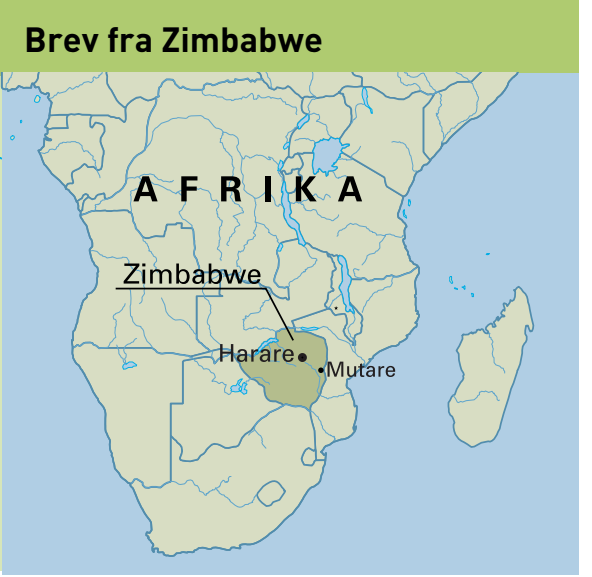

gitt infisert drikkevann (fig 2). Da jeg forlot landet $\mathrm{i}$ begynnelsen av februar, hadde epidemien krevd 3229 menneskeliv blant i alt 63000 rapporterte tilfeller (1). Det gir en dødsrate på over $5 \%$, fem ganger høyere enn forventet ved tilfredsstillende behandling. Per 27.7. var tallene steget til 4288 dødsfall og 98592 tilfeller (2). I løpet av juli 2009 ble det imidlertid ikke rapportert nye tilfeller av kolera (3).

Ved sykehuset utenfor Mutare, som drives av United Methodist Mission (UMC), finner jeg den eneste norske helsearbeideren i hele Zimbabwe, sykepleier Ragnhild Sand som reiser ut med helseteam til landsbyene. Sykehusets protokoll viser at det i perioden 21.11. 2008-2.2. 2009 ble innlagt 215 kolerapasienter, hvorav 17 døde. Hele 95 av pasientene kom fra landsbyer langs elven Save. Et medisinsk team har besøkt landsbyene for å undervise i hygiene og dele ut vannrensetabletter. Fra 11.12. 2008 fikk Leger Uten Grenser etablert en isolasjonsavdeling ved sykehuset med tilgang på medikamenter, elektrolyttløsning (ORS) og intravenøs behandling, i tillegg til desinfeksjon av skoene til de som kommer og går. Fra da av døde ingen pasienter og ingen av staben ble syke. Når jeg besøker sykehuset, er det bare to pasienter $i$ avdelingen, og epidemien synes å være på hell i området utenfor Mutare. Den siste dagen jeg er der, kommer det inn en svært syk ni år gammel jente.

\section{En aktuell rapport}

Den dagen jeg reiser fra landet, frigir Leger for menneskerettigheter (Physicians for Human Rights, PHR) en rapport med tittelen Health in ruins - a man-made disaster in Zimbabwe (1). Her levnes Mugabe og hans partifeller i Zanu-PF liten ære. «Denne situasjonen er brudd på menneskerettighetene,» sier organisasjonen og sikter til mangel på rent vann, mat og helse - i tillegg til tortur. Zimbabwe var det sørlige Afrikas kornkammer, jordbruket bidro med 